\title{
Occurrence of trace organic contaminants in Bohai Bay and its adjacent Nanpaiwu River, North China
}

\author{
Jianying $\mathrm{Hu}^{\mathrm{a}, *}$, Yi Wan ${ }^{\mathrm{a}}$, Bing Shao ${ }^{\mathrm{a}, \mathrm{b}}$, Xiaohui Jin ${ }^{\mathrm{a}}$, Wei $\mathrm{An}^{\mathrm{a}}$, Fen Jin ${ }^{\mathrm{a}}$, Min Yang ${ }^{\mathrm{b}}$, \\ Xiaoju Wang ${ }^{\mathrm{c}}$, Mituo Sugisaki ${ }^{\mathrm{c}}$ \\ ${ }^{\mathrm{a} C o l l e g e}$ of Environmental Science, Beijing University, Beijing 100871, China \\ ${ }^{\mathrm{b}}$ State Key Lab of Environmental Aquatic Chemistry, Research Center for Eco-Environmental Sciences, Chinese Academy of Sciences, \\ Beijing 100085, China \\ ${ }^{\mathrm{c}}$ Center for Environmental Science in Saitama (CESS), 914 Kamitanadare Kisai T. Kitasakitama-gun Saitama Pref. 347-0115, Japan
}

Received 9 October 2003; received in revised form 24 May 2004; accepted 24 June 2004

Available online 29 December 2004

\begin{abstract}
Concentrations of hexachlorocyclohexanes (HCHs), hexachlorobenzene (HCB), pentachlorobenzene (penta-CB), polychlorinated dibenzo- $p$-dioxins (PCDDs), polychlorinated dibenzofurans (PCDFs), coplanar polychlorinated biphenyls (co$\mathrm{PCBs}$ ), 1,1,1-trichloro-2,2-bis ( $p$-chlorophenyl)ethane (DDTs, including $p, p^{\prime}$-DDT; $o, p^{\prime}$-DDT; $p, p^{\prime}$-DDD; $o, p$-DDD; $p, p^{\prime}$-DDE; $o, p^{\prime} \mathrm{DDE} ; p, p$ 'DDMU), nonylphenol (NP), and nonylphenol polyethoxylates (NPEOs) were measured in sedimentary cores from Bohai Bay (one core) and its adjacent river, the Nanpaiwu River (two cores), North China. While $\alpha-$, $\beta$-, and $\gamma$-HCHs were detected in similar abundance in the two cores from the Nanpaiwu River, only $\alpha-\mathrm{HCH}$ was detected in the Bohai Bay core, suggesting that $\alpha-\mathrm{HCH}$ might be more resistant to degradation than $\beta$ - or $\gamma$-HCHs. The concentrations of HCHs and HCB in the core from Bohai Bay were in the range of $0.8-140$ and $9.1-1300 \mathrm{ng} / \mathrm{g}$ dry wt, respectively, whereas in the cores from the Nanpaiwu River, the maximum concentrations of HCHs and HCB reached 84,200 and 141,400 ng/g dry wt, respectively. There was a similarity of sedimentary profiles between $\mathrm{HCHs}$ and $\mathrm{HCB}$ in the three cores. The concentration of PCDDs/DFs in Bohai Bay was $0.5-3.5 \mathrm{ng} / \mathrm{g}$ dry wt [1.6-6.4 toxic equivalents (TEQ) world health organization (WHO) $\mathrm{pg} / \mathrm{g}$ ], far lower than the concentrations in the core samples taken from the Nanpaiwu River (the maximum concentration: $9200 \mathrm{ng} / \mathrm{g}$ dry wt; 22,000 TEQ WHO pg/g). The congener profiles of PCDD/DFs and co-PCB in the cores were similar to those in PCP, and the concentration of co-PCBs was related to that of PCDDs/DFs. In addition, the concentrations of $\mathrm{HCH}, \mathrm{HCB}, \mathrm{PCDD} / \mathrm{Fs}$, and co-PCB all decreased linearly relative to total organic carbon content (TOC) in surface sediment from the river to Bohai Bay. The concentration of DDTs ranged from 1.6 to $12.3 \mathrm{ng} / \mathrm{g}$ dry wt in Bohai Bay, significantly different from the profiles from the Napaiwu River (29.3 ng/g dry wt). An abundance of the compounds $o, p$-DDE and $o, p$-DDD were detected in the cores. The sedimentary profiles of NP and NPEOs were similar, and two peak concentrations of NP/NPEOs were found at the subsurface and subbottom in the core from Bohai Bay, respectively. The concentration of NP and NPEOs in the cores from the Nanpaiwu
\end{abstract}

\footnotetext{
* Corresponding author. Tel./fax: +86 1062765520 .

E-mail address: hujy@urban.pku.edu.cn (J. Hu).
} 
River were about 15 times higher than those in the core from Bohai Bay, suggesting that the Nanpaiwu River was possibly one of the sources of NP and NPEOs in Bohai Bay.

(c) 2004 Published by Elsevier B.V.

Keywords: Sedimentary core; Organochlorine contaminants; Dioxins; NP; NPEOs; Bohai Bay

\section{Introduction}

Numerous papers have highlighted the potentially detrimental reproductive effects of certain anthropogenic compounds on wildlife and humans. Organic compounds reported to disrupt normal reproductive pathways in animals include pesticides, certain polychlorinated biphenyls (PCBs), polychlorinated dibenzo- $p$-dioxins (PCDDs), dibenzofurans (PCDFs), and alkylphenols (Miyamoto and Klein, 1998). With respect to the latter, 4-nonylphenol (4-NP) is of growing concern due to its estrogenic effects on aquatic organisms (Soto et al., 1991; Jobling and Sumpter, 1993; White et al., 1994) and its prevalence in the environment (Lye et al., 1999; Thiele et al., 1997). The residual 4-NP in the aqueous environment predominantly stems from the wide use of nonylphenol polyethoxylate (NPEOs) surfactants of various ethoxylate chain lengths. While much research has focused on NP monitoring in aquatic environments, there have been few studies on the occurrence of its precursor, NPEOs with an ethoxylate length of more than 2 (Shang et al., 1999; Jonkers et al., 2003).

Organochlorine pesticides such as hexachlorocyclohexanes (HCHs), dichlorodiphenyltrichloroethane (DDT) and its metabolite, and hexachlorobenzene (HCB) are of global concern due to their intensive use for agricultural and industrial purposes in developing countries in the past few decades. Although the application of organochlorine pesticides has been banned in developed countries, they are still ubiquitous in marine, freshwater, and estuarine food chains (Maruyama et al., 2000; Tanabe et al., 1994; Iwata et al., 1994; Bard, 1999; Glynn et al., 1995), and have been associated with abnormal development of the reproductive system of wild animals (Simonich and Hites, 1995; Connell et al., 2003; Weber and Goerke, 1996). Another category of compounds of global concern is dioxins including co-PCB. Surveys on the status of their pollution has been carried out in sediment cores (Czuczwa and Hites, 1984; Kjeller and Rappe, 1995; Juttner et al., 1997; Vartiainen et al., 1997; Wu et al., 1997) and indicates that dioxin pollution is now in remediation in developed countries, although sediment cores from remote lakes in Germany and Finland showed increasing trends until recent years (Vartiainen et al., 1997). The abovementioned compounds can enter into the sea through coastal processes (riverine discharges and run-off homeland), perhaps to be stored in sediments at the seabed or diluted and dispersed across the continental shelf and beyond to the global ocean.

Although the usage of DDT, industrial $\mathrm{HCH}$ and HCB were banned in China in 1983, DDT (Mao, $1995)$ is still produced as a raw material for manufacturing of the pesticide: Dicofol (outputs of dicofol: 2000 tons). Moreover, the stock of HCHs produced before the 1980s is still used as raw material for production of pentachlorophenolic sodium (PCP), and HCB is a byproduct of PCP production, in which the concentration of dioxins (including PCDD/DFs and co-PCBs) is about $7420 \mathrm{ng} / \mathrm{g}$ dry wt $(360$ ngWHO-TEQ/g) (Kim, 2002). The total output of PCP pesticide was about 25.6 ktons from 1962 to 1999 in China (China chemical plant statistical data, 2000); however, information about dioxins and HCB residue in China's aqueous environment is fragmentary compared with that of DDTs and HCHs. The environmental effects and fate of NPEOs have received little attention in China, although the annual output of NPEOs reached 50 ktons in 1997, about one-tenth of the total output worldwide (Nalor, 1996).

Bohai Bay is a large, semienclosed shallow water basin located along the western region of the Bohai Sea in the northeastern part of China. Input of continental wastewater to Bohai Bay is largely from the Nanpaiwu River. This river receives industrial and municipal wastewaters from Tianjin City which has many chemical factories, including the largest DDT and PCP producer in the country. A systematic survey on inputs of the above chemical pollutants from Tianjin City to Bohai Bay has never been conducted 
despite the fact that the Bohai Sea is an important fishery area in China. In this study, we report concentrations of HCHs, HCB, PCDDs, PCDFs and co-PCBs, DDTs, NP and NPEOs in three sedimentary cores, one from Bohai Bay and two from the adjacent Nanpaiwu River, to provide information on the potential source of these chemicals in Bohai Bay.

\section{Materials and methods}

\subsection{Sampling location}

Fig. 1 shows the sampling locations. The area of estuary coast around Bohai Bay is about $170,000 \mathrm{~km}^{2}$, and the population is about 70 million. Approximately $87 \%$ of pollutants in Bohai Bay are discharged from land, and $95 \%$ of pollutants generated in the area are transported by rivers into Bohai Bay (Liu et al., 2003). With an area about $80,000 \mathrm{~km}^{2}$ and the average water depth about $18 \mathrm{~m}$, Bohai Bay is a typical inner sea located in the northeast region of China. The
Nanpaiwu River is a major source of wastewater to Bohai Bay. It receives industrial and domestic wastewater from the cities of Tianjin and Beijing, and is the most heavily polluted river in the Haihe basin. A sediment core was collected from Bohai Bay (Station C-3; N38 $57^{\prime}$, E $117^{\circ} 44$ ), and two from the Nanpaiwu River (Station C-1 and C-2; N38 $59^{\prime}$, E117 $39^{\prime}$ and $\mathrm{N} 38^{\circ} 58^{\prime}, \mathrm{E} 117^{\circ} 41^{\prime}$, respectively) using a 2-m-long, 10$\mathrm{cm}$ diameter box corer in November 2002. The cores were sliced into 5-cm-thick disks immediately after collection using a stainless steel slicer. Each section was stored at $-20{ }^{\circ} \mathrm{C}$ until analysis.

\subsection{Reagents}

$\alpha-, \beta-, \gamma-\mathrm{HCH} ; o, p^{\prime}$-DDD; $p, p^{\prime}$-DDD; $o, p^{\prime}$-DDT; $p, p$-DDT; $o, p^{\prime}$-DDE; and $p, p^{\prime}$-DDE were all purchased from Chemservice (Chester, England) and $p, p$-DDMU was from Sigma. HCB and penta-CB were purchased from Accu Standard (CT, USA). Nonylphenol mono-ethoxylate $\left(\mathrm{NP}_{1} \mathrm{EO}\right)$, nonylphenol di-ethoxylate $\left(\mathrm{NP}_{2} \mathrm{EO}\right)$, nonylphenol tri-ethoxy-

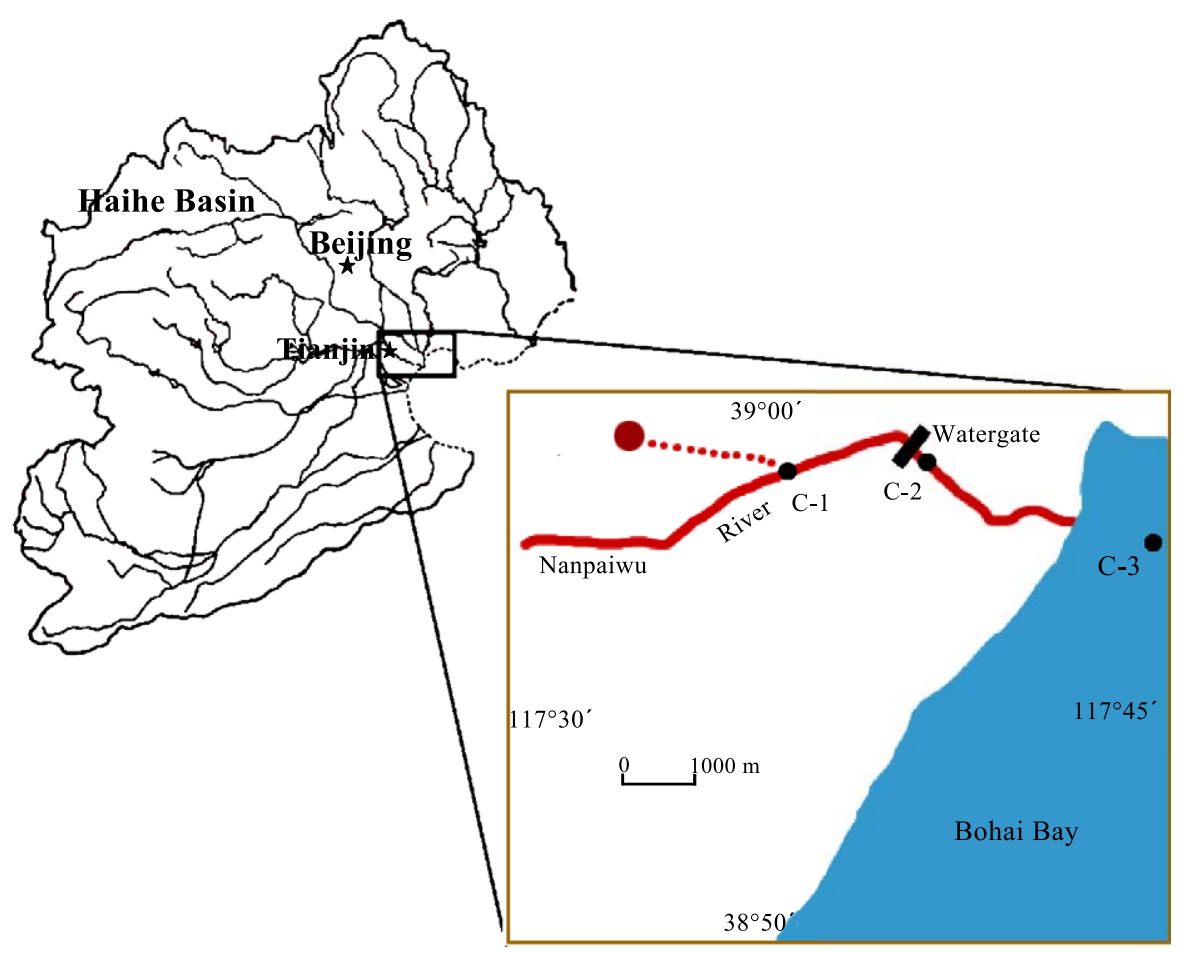

Fig. 1. Map of sampling locations. C-1: from the Nanpaiwu River, N38 $59^{\prime} \mathrm{E} 117^{\circ} 39^{\prime}, \mathrm{C}-2$ : from the Nanpaiwu River, N38 $58^{\prime} \mathrm{E} 117^{\circ} 41^{\prime}, \mathrm{C}-3$ : from Bohai Bay, $\mathrm{N} 38^{\circ} 58^{\prime} \mathrm{E} 117^{\circ} 44^{\prime}$ : Industrial zone; $\cdots \cdots .$. : drainage pipe. 
late $\left(\mathrm{NP}_{3} \mathrm{EO}\right)$, nonylphenol tetra-ethoxylate $\left(\mathrm{NP}_{4} \mathrm{EO}\right)$, nonylphenol penta-ethoxylate $\left(\mathrm{NP}_{5} \mathrm{EO}\right)$, nonylphenol hexa-ethoxylate $\left(\mathrm{NP}_{6} \mathrm{EO}\right)$, and a mixture of NPEOs with an average of 15 EO units were obtained from Hayashi Pure Chemicals (Tokyo, Japan). PCDDs/PCDFs, co-PCBs and their internal standards were from Wellington Laboratories (Ontario, Canada).

\subsection{Chemical analysis}

\subsection{1. $H C H s, H C B$, penta-CB, DDTs, NP, and NPEOs}

Sediments were air-dried and $10 \mathrm{~g}$ dry samples (mixed with $20 \mathrm{~g} \mathrm{Na}_{2} \mathrm{SO}_{4}$ ) spiked with recovery surrogate (PCB 30; IUPAC) were Sohxlet extracted for $24 \mathrm{~h}$ using $200 \mathrm{ml}$ dichloromethane/methanol (7:3 $\mathrm{v} / \mathrm{v})$ mixture solution. Extracts were passed through 12 g $5 \% \mathrm{H}_{2} \mathrm{O}$ deactivated neutral $\mathrm{Al}_{2} \mathrm{O}_{3}$ (200 mesh size, Shanghai Ludu Chemicals, China) packed in a glass column (10 $\mathrm{mm}$ i.d.) for cleanup and fractionation. The first fraction eluted with $30 \mathrm{ml}$ high-purity hexane, $30 \mathrm{ml}$ hexane/dichloromethane $(3: 1 \mathrm{v} / \mathrm{v})$ contained HCHs, DDTs, penta-HCB, and HCB. NP and NPEOs were eluted in the second fraction with 30 $\mathrm{ml}$ hexane/dichloromethane $(50: 50 \mathrm{v} / \mathrm{v}), 40 \mathrm{ml}$ dichloromethane, and $30 \mathrm{ml}$ dichloromethane/methanol $(85: 15 \mathrm{v} / \mathrm{v})$, and $30 \mathrm{ml}$ dichloromethane/methanol $(50: 50 \mathrm{v} / \mathrm{v})$. HCHs, HCB, DDTs, and NP were determined by gas chromatography-mass spectrometers (GC-MS). And NPEOs were analyzed using an electrospray ionization-liquid chromatography-mass spectrometers (ESI-LC-MS) method (Shao et al., 2002).

GC-MS analysis was performed with a HewlettPackard 5890 gas chromatograph connected to a Hewlett-Packard 5971 mass spectrometer. The mass spectrometer was operated in the electron impact ionization mode with an ionizing energy of $70 \mathrm{eV}$. The injector temperature was maintained at $250{ }^{\circ} \mathrm{C}$, and the source temperate was kept at $280{ }^{\circ} \mathrm{C}$. An HP-5MS capillary column $(30 \mathrm{~m} \times 0.25 \mathrm{~mm}$ i.d. with a film thickness of $0.25 \mu \mathrm{m}$ ) used for HCHs, HCB, DDTs analysis was programmed to increase from $50{ }^{\circ} \mathrm{C}(2$ min) to $186{ }^{\circ} \mathrm{C}$ at $10{ }^{\circ} \mathrm{C} / \mathrm{min}$ (keeping this temperature for $2 \mathrm{~min}$ ), and to $235{ }^{\circ} \mathrm{C}$ at $5{ }^{\circ} \mathrm{C} / \mathrm{min}$, which was held for $2 \mathrm{~min}$. The same capillary column for NP analysis was programmed from $50{ }^{\circ} \mathrm{C}(2 \mathrm{~min})$ to $200{ }^{\circ} \mathrm{C}$ at 20 ${ }^{\circ} \mathrm{C} / \mathrm{min}$ (keeping this temperature for $2 \mathrm{~min}$ ), and to
$260{ }^{\circ} \mathrm{C}$ at $5{ }^{\circ} \mathrm{C} / \mathrm{min}$. The injection volume was $2 \mu \mathrm{l}$, and splitless mode was used.

LC-MS was performed on an Alliance 2690 HPLC (Waters, USA) equipped with a quaternary gradient pump, an autosampler with $100 \mathrm{ml}$ injection loop, a $\mathrm{C}_{18}$ precolumn $(2.1 \mathrm{~mm}$ in $\mathrm{ID} \times 50 \mathrm{~mm}$ in length, 3 $\mathrm{mm}$ Capcell Pak, Shiseido, Japan) and a silica analytical column $(2.1 \mathrm{~mm}$ in $\mathrm{ID} \times 150 \mathrm{~mm}, 3 \mathrm{~mm}$ Spherisorb SW3, Waters). The flow was kept at 0.1 $\mathrm{ml} / \mathrm{min}$ for $1 \mathrm{~min}$ with $100 \%$ acetonitrile, then increased linearly to $0.35 \mathrm{ml} / \mathrm{min}$ over $34 \mathrm{~min}$. The solvent composition was changed linearly to $75 \%$ acetonitrile $/ 25 \%$ water over $35 \mathrm{~min}$, then linearly to $100 \%$ acetonitrile over $5 \mathrm{~min}$, while the flow was kept at $0.35 \mathrm{ml} / \mathrm{min}$ for $10 \mathrm{~min}$. Flow was then held at 0.1 $\mathrm{ml} / \mathrm{min}$ for $40 \mathrm{~min}$ to equilibrate the columns before the next injection. A platform ZMD single-quadrupole mass spectrometry (Micromass, Manchester, UK) was used with a Z-Spray ion-source fitted with a pneumatically assisted electrospray probe. In the positive mode, typical ion source parameters were used as follows: ESI capillary voltage at $3.5 \mathrm{kV}$; extractor voltage at $5 \mathrm{~V}$; source block temperature at $120{ }^{\circ} \mathrm{C}$; desolvation temperature at $1800{ }^{\circ} \mathrm{C}$; ion energy at 0.8 $\mathrm{V}$; multiplier voltage at $650 \mathrm{~V}$. Nitrogen was used as the desolvation gas with a flow rate between 270 and $350 \mathrm{l} / \mathrm{h}$ and cone gas with a rate of $70-100 \mathrm{l} / \mathrm{h}$; the cone voltage was ramped from 25 to $70 \mathrm{~V}$ with the full scan mass ranging from 280 to 1500 dalton with a scan time of $1.2 \mathrm{~s}$.

Dichloromethane, methanol, and hexane were HPLC grade or pesticide grade from Fisher Scientific (NJ, USA). The procedure described above was validated for recoveries (ranging from $89 \%$ to $120 \%$ for $\mathrm{HCHs}, 99 \%$ to $113 \%$ for DDTs, $92 \%$ to $105 \%$ for NPEOs, $80 \%$ for NP, and $101 \%$ for penta-CB and HCB). Percent recovery of surrogate determined in sediment was $76.3 \pm 9.7 \%$, and concentrations reported here have not been corrected for recovery. Precision is estimated at better than $20 \%$ based on analysis of three replicate samples collected in Nanpaiwu River.

\subsubsection{PCDDs, $P C D F s$, and $c o-P C B s$}

Sediments were air-dried and $20 \mathrm{~g}$ dry samples were Soxhlet extracted with toluene for $24 \mathrm{~h}$. After the addition of $17{ }^{13} \mathrm{C}$-labeled PCDD/F and $14{ }^{13} \mathrm{C}$ labeled $\mathrm{Co}-\mathrm{PCB}$ internal standards, the extracts were 
first treated with concentrated sulfuric acid. The extract was then passed through $1 \mathrm{~g}$ silica gel (Wako Pure Chemical Industries, Japan) and 2 g 44\% $\mathrm{H}_{2} \mathrm{SO}_{4}$ silica gel (Wako Pure Chemical Industries) packed in a glass funnel by eluting with $50 \mathrm{ml}$ hexane. After being treated with activated copper, concentrated extracts were passed through $10 \%$ $\mathrm{AgNO}_{3}$ silica gel (Wako Pure Chemical Industries) and activated carbon-impregnated silica gel (Kanto Chemical, Japan) columns. The silica gel column was packed with $2 \mathrm{~g} 10 \% \mathrm{AgNO}_{3}$ silica gel heated at $130{ }^{\circ} \mathrm{C}$ for $3.5 \mathrm{~h}$, and $200 \mathrm{ml}$ hexane was utilized for elution. The activated carbon-impregnated silica gel column was packed with $1 \mathrm{~g}$ activated carbon dispersed silica gel. This column was first eluted with $40 \mathrm{ml}$ hexane and then $250 \mathrm{ml}$ toluene. The last fraction was concentrated and spiked with two ${ }^{13} \mathrm{C}$ labeled $\mathrm{PCDD} / \mathrm{F}$ and four ${ }^{13} \mathrm{C}$-labeled $\mathrm{Co}-\mathrm{PCB}$ internal standards for high-resolution GC (HewlettPackard HP 6890)/high-resolution MS (JMS-700 MS Spectrometer, JEOL, Japan) analysis. CP-Si1188 (length, $60 \mathrm{~m}$; inner diameter, $0.32 \mathrm{~mm}$; film thickness, $0.13 \mu \mathrm{m}$; Chrompack) was used to separate TCDD/Fs, PCDD/Fs, and some HCDD/Fs. The column oven temperature was programmed to increase from $100{ }^{\circ} \mathrm{C}(1 \mathrm{~min})$ to $180{ }^{\circ} \mathrm{C}$ at a rate of $20{ }^{\circ} \mathrm{C} / \mathrm{min}$, and then to $260{ }^{\circ} \mathrm{C}$ at a rate of $3{ }^{\circ} \mathrm{C} / \mathrm{min}$, which was maintained for $20 \mathrm{~min}$. The congeners of $\mathrm{HpCDD} / \mathrm{Fs}$, OCDD/Fs, and some of $\mathrm{HCDD} / \mathrm{Fs}$ were separated on a DB-17 capillary column coated at $0.25 \mu \mathrm{m}$ (length, $30 \mathrm{~m}$; inner diameter, $0.25 \mathrm{~mm}$; J \& W Scientific). The column oven temperature was: $120{ }^{\circ} \mathrm{C}$ for $2 \mathrm{~min}, 20{ }^{\circ} \mathrm{C} / \mathrm{min}$ to $180{ }^{\circ} \mathrm{C}$, and $4{ }^{\circ} \mathrm{C} / \mathrm{min}$ to $300{ }^{\circ} \mathrm{C}$, maintained for $3 \mathrm{~min}$. DB-5 (length, $60 \mathrm{~m}$; inner diameter, $0.25 \mathrm{~mm}$; film thickness, $0.25 \mu \mathrm{m}$; J\&W Scientific) was used to separate $\mathrm{Co}-\mathrm{PCBs}$ with the same temperature program of DB-17. The mass spectrometer was operated at a resolution of more than 10,000 and in a selected ion-monitoring (SIM) mode. Both the injector and the ion source were kept at $260{ }^{\circ} \mathrm{C}$. The electronimpact ionization energy was $38 \mathrm{eV}$ and the ion current was at $500 \mu \mathrm{A}$. The PCDD/PCDF congeners were monitored by SIM mode at the two most intensive ions at the molecular ion cluster. Recoveries of ${ }^{13} \mathrm{C}$-labelled PCDD and PCDF congeners through the analytical procedure ranged from $70 \%$ to $110 \%$.

\subsection{Total organic carbon analysis}

Dry sediment (about $5 \mathrm{mg}$ ) was put into small precombusted $\left(600{ }^{\circ} \mathrm{C}, 4 \mathrm{~h}\right)$ quartz sample boats. Phosphoric acid (44\%) was added to remove inorganic carbon in the sample. Finally, the sample was analyzed using a Total Organic Carbon (TOC) Analyzer (Apollo 9000, Tekmar-Dohrmann, USA).
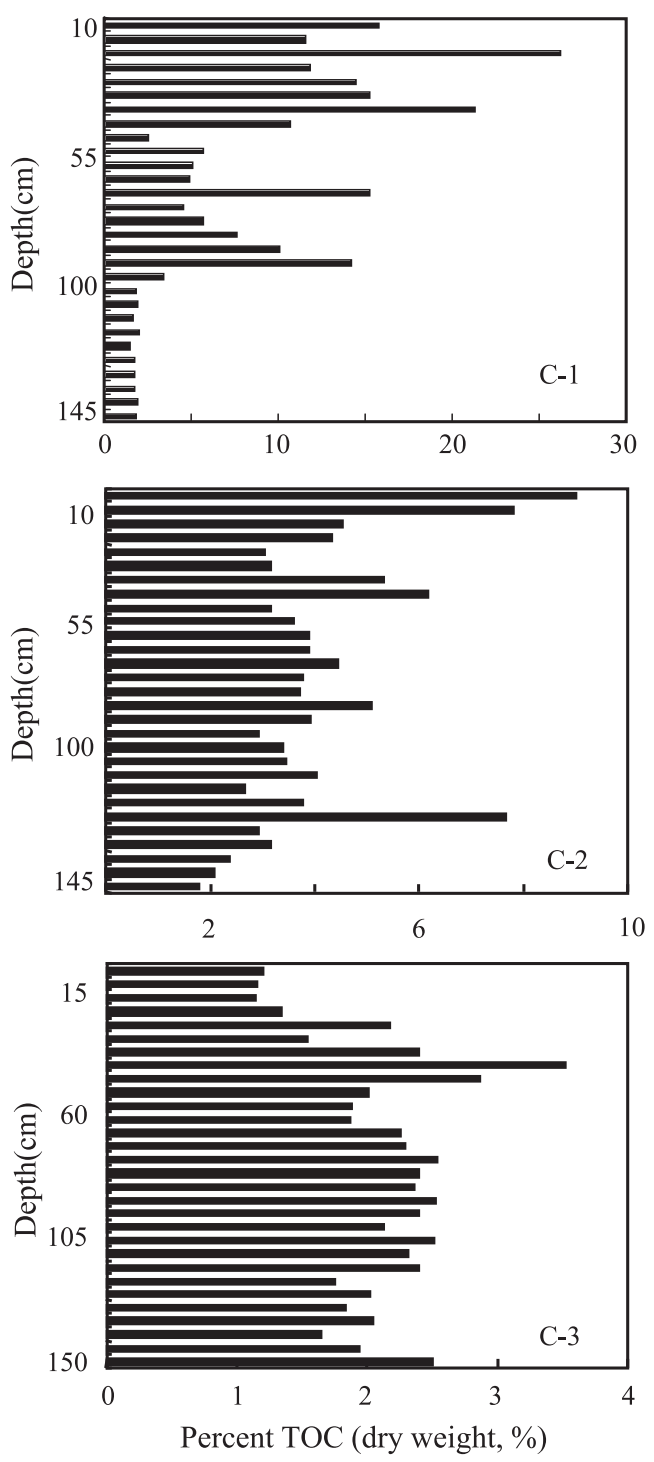

Fig. 2. Vertical profiles of TOC content ( $\%$ dry wt) in sedimentary cores from Bohai Bay and its adjacent Nanpaiwu River. C-1, C-2: sedimentary cores from the Nanpaiwu River; C-3: sedimentary core from Bohai Bay. 


\section{Results and discussion}

\section{1. $H C H s, H C B$, and penta-CB}

Fig. 2 shows the vertical profiles of TOC in the three sediment cores and Fig. 3 shows the vertical profiles of total $\mathrm{HCHs}, \mathrm{HCB}$, and penta-CB. The concentrations of $\mathrm{HCH}, \mathrm{HCB}$ in three cores are much higher than those reported by Khim et al. (1999) in Masan Bay, Korea. This maybe due to a direct discharge of wastewater from PCP manufacturing plant where $\mathrm{HCH}$ is the raw material and $\mathrm{HCB}$ is an intermediate into Bohai Bay through Nanpaiwu River, while there is little farming activity around Masan Bay and OC pesticide use was banned in Korea in the 1970s. Of three HCHs $(\alpha-, \beta-$, and $\gamma$ $\mathrm{HCH}$ ), only $\alpha-\mathrm{HCH}$ was detected in all sections of core C-3 from Bohai Bay. In this core, the highest concentration was $140 \mathrm{ng} / \mathrm{g}$ dry wt at a depth of 65 to $70 \mathrm{~cm}$ followed by $83.0 \mathrm{ng} / \mathrm{g}$ dry wt at the bottom of
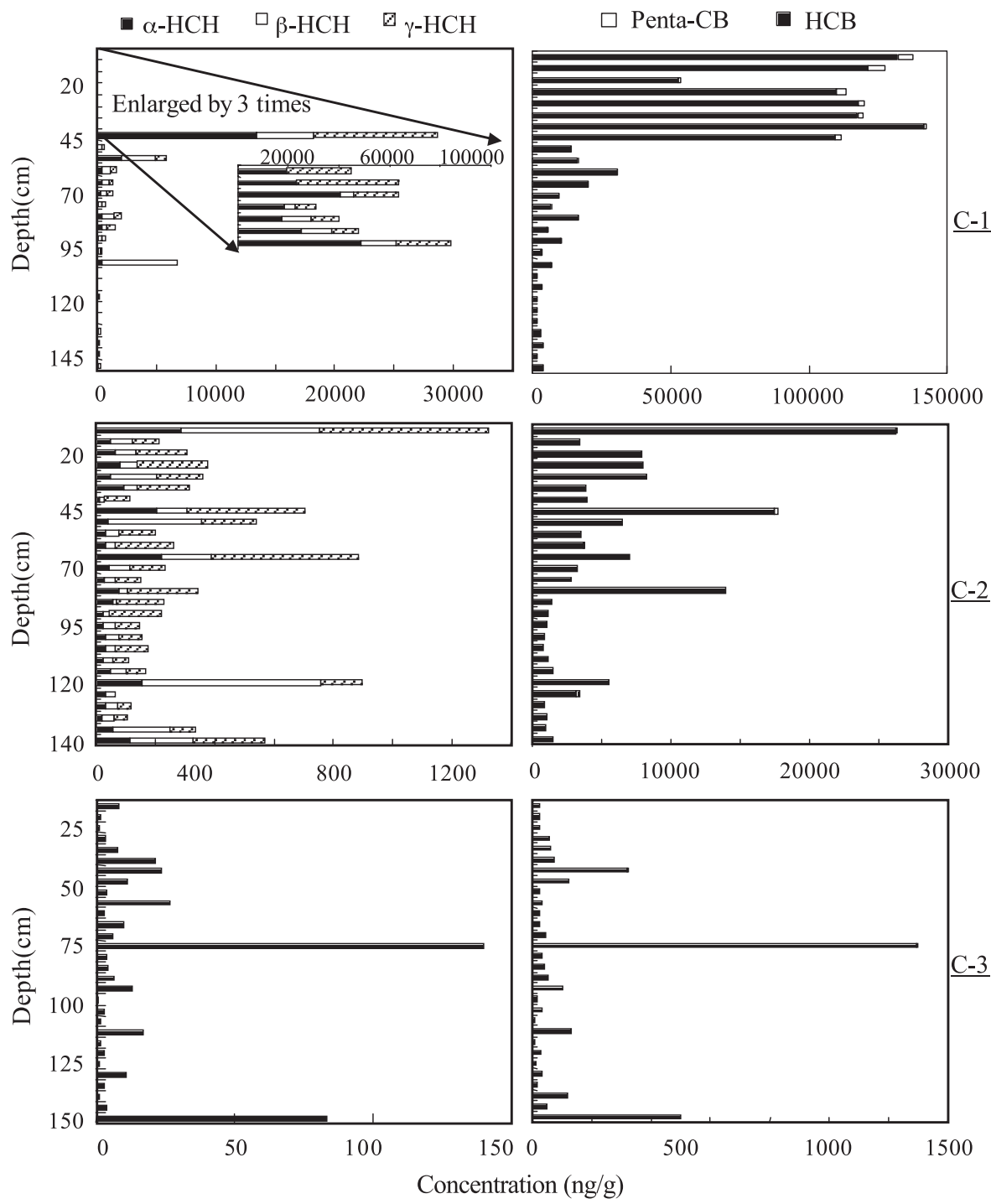

Fig. 3. Vertical profiles of $\mathrm{HCH}, \mathrm{HCB}$ and penta-CB concentrations in sedimentary cores from Bohai Bay and its adjacent Nanpaiwu River. C-1, C-2: sedimentary cores from the Nanpaiwu River; C-3: sedimentary core from Bohai Bay. 
the core. At the other depths, the concentration of $\alpha$ $\mathrm{HCH}$ was in a range from 0.8 to $27.0 \mathrm{ng} / \mathrm{g}$ dry wt. Similarly, the profile of HCB was also characterized by two concentration maxima at depths coincident with those of $\alpha-\mathrm{HCH}$ (i.e., a maximum concentration of $1300 \mathrm{ng} / \mathrm{g}$ dry wt followed by $501 \mathrm{ng} / \mathrm{g}$ dry wt). In the other sections, HCB concentrations ranged from 14.8 to $319 \mathrm{ng} / \mathrm{g}$ dry wt. The similar profiles of $\mathrm{HCH}$ and HCB imply that they might originate from a common source. The total organic carbon content (TOC) in the sediment intervals of C-3 were between $1.1 \%$ and $3.5 \%$ and the variation was small (Fig. 2). From the vertical profile, no relationship was found between TOC and the concentration of $\mathrm{HCHs}$ and HCB.

In contrast with $\mathrm{C}-3$, the vertical profiles of $\mathrm{HCH}$ isomers and $\mathrm{HCB}$ in core $\mathrm{C}-2$ and $\mathrm{C}-1$ demonstrate that all of the $\mathrm{HCH}$ isomers existed in the Nanpaiwu River. In both of $\mathrm{C}-2$ and $\mathrm{C}-1$, the profile of total $\mathrm{HCHs}$ is similar to that of $\mathrm{HCB}$, suggesting that $\mathrm{HCHs}$ and $\mathrm{HCB}$ might be discharged from the same sources. The maximum concentration of total $\mathrm{HCHs}$ in C-2 was $1300 \mathrm{ng} / \mathrm{g}$ dry wt at the surface, 20 times higher than the lowest concentration $(65.5 \mathrm{ng} / \mathrm{g}$ dry wt; $120-125 \mathrm{~cm})$. The maximum concentration of HCB (26,200 ng/g dry wt) was also observed at the surface, 30 times higher than the lowest concentration (799 ng/g dry wt). In addition, penta-CB was also detected in a range from 4.5 to $261 \mathrm{ng} / \mathrm{g}$ dry wt. For core $\mathrm{C}-1$, the highest concentrations of total $\mathrm{HCHs}$ and HCB were 84,200 and $141,400 \mathrm{ng} / \mathrm{g}$ dry wt, which were 194 and 100 times higher than the lowest concentration of 106 and $1400 \mathrm{ng} / \mathrm{g}$ dry wt, respectively. In addition, penta-CB was also detected to be in a range from 5400 (surface) to $2200 \mathrm{ng} / \mathrm{g}$ dry wt (40 $\mathrm{cm})$. Both HCHs and HCB showed the same increasing trend with the decrease of core depth in $\mathrm{C}-2$ and $\mathrm{C}-1$, indicating a recent increase in pollutant discharge. Such a trend was also found in the vertical profiles of TOC in C-1 and C-2 (Fig. 2).

From the above results, it is clear that estuarine $\mathrm{HCHs}$ in Nanpaiwu River sediments (C-1 and C-2) were significantly higher than those in the sediment from Bohai Bay. Fig. 4 shows the relationship between concentration of $\mathrm{HCHs}$ and $\mathrm{HCB}$ and TOC in surface intervals from $\mathrm{C}-1, \mathrm{C}-2$, and $\mathrm{C}-3$. It was found that the spatial distribution in $\mathrm{C}-1, \mathrm{C}-2$, and $\mathrm{C}-3$ was related with TOC in sediment, indicating that the

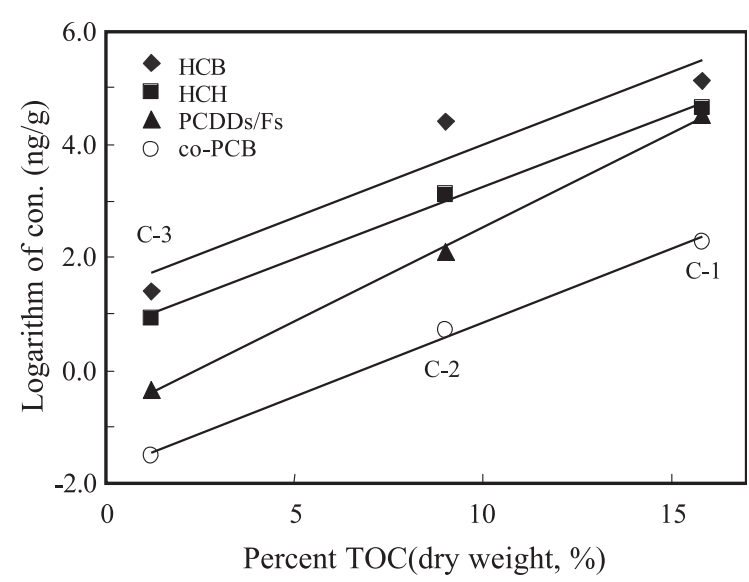

Fig. 4. Relationship between concentrations of PCDD/Fs, co-PCB, $\mathrm{HCH}, \mathrm{HCB}$ and TOC in surface section from $\mathrm{C}-1, \mathrm{C}-2$ and $\mathrm{C}-3$. $\mathrm{HCH}, \mathrm{HCB}$, and co-PCB: slope $=0.26$, PCDDs/Fs: slope $=0.33$.

riverine discharge was the likely source of contamination in Bohai Bay.

It is interesting to note that while $\alpha-\mathrm{HCH}$ concentration reached $139 \mathrm{ng} / \mathrm{g}$ dry $\mathrm{wt}, \beta-\mathrm{HCH}$ and $\gamma-\mathrm{HCH}$ were not detected in Bohai Bay (C-3) samples, although the latter were detected at a relatively high ratio to $\alpha-\mathrm{HCH}$ in estuarine sediment from the Nanpaiwu River (C-1 and C-2). One explanation for this is that $\alpha$ $\mathrm{HCH}$ might be the most persistent $\mathrm{HCH}$ in the coastal sedimentary environment, although $\beta-\mathrm{HCH}$ was reported to be the most persistent with respect to microbial degradation (Willett et al., 1998). Further studies are required to verify the above speculation.

\section{2. $P C D D s, P C D F s$, and $c o-P C B$}

The concentration of total PCDDs/DFs in Bohai Bay (C-3) ranged from 430 to $3100 \mathrm{pg} / \mathrm{g}$ dry wt (Table 1 ), which is lower than that reported in Tokyo Bay, where the PCDDs/DFs originated from several independent sources: use of PCP and chloronitrofen (CNP), emission from municipal solid waste incineration (MSWI), municipal sewage sludge, etc (Yamashita et al., 2000). The concentration of PCDDs was over 10 times higher than that of PCDFs. The maximum concentrations of PCDDs and PCDFs were observed at depths $50-100 \mathrm{~cm}$. On the other hand, the maximum concentrations of $\mathrm{PCDD} / \mathrm{DF}$ in the $\mathrm{C}-2$ and $\mathrm{C}-1$ cores were 151.1 and $8714.5 \mathrm{ng} / \mathrm{g}$ dry wt, respectively, about 50 times and 3000 times higher than that in core (C-3) from Bohai Bay. The congener 
Table 1

Concentrations (pg/g dry wt) of PCDDs and PCDFs in the sediment from the Nanapaiwu River and Bohai Bay, North China

\begin{tabular}{|c|c|c|c|c|c|c|c|c|c|c|c|c|c|c|c|}
\hline \multirow[t]{2}{*}{ Depth (cm) } & \multicolumn{4}{|l|}{ C-1 } & \multicolumn{4}{|l|}{$\mathrm{C}-2$} & \multicolumn{7}{|l|}{$\mathrm{C}-3$} \\
\hline & $0-5$ & $\begin{array}{l}25- \\
30\end{array}$ & $\begin{array}{l}85- \\
90\end{array}$ & $\begin{array}{l}135- \\
140\end{array}$ & $0-5$ & $\begin{array}{l}50- \\
55\end{array}$ & $\begin{array}{l}95- \\
100\end{array}$ & $\begin{array}{l}135- \\
140\end{array}$ & $0-5$ & $\begin{array}{l}45- \\
50\end{array}$ & $\begin{array}{l}65- \\
70\end{array}$ & $\begin{array}{l}85- \\
90\end{array}$ & $\begin{array}{l}105- \\
110\end{array}$ & $\begin{array}{l}125- \\
130\end{array}$ & $\begin{array}{l}145- \\
150\end{array}$ \\
\hline $\begin{array}{l}\text { 2378- } \\
\text { TeCDD }\end{array}$ & 0.0 & 500 & 11.0 & 2.2 & 28.0 & 31.0 & 14.0 & 3.8 & 0.3 & 0.2 & 0.4 & 0.1 & 0.1 & 0.07 & 0.2 \\
\hline $\begin{array}{l}\text { 12378- } \\
\text { PeCDD }\end{array}$ & 2000 & 800 & 26.0 & 3.8 & 61.0 & 62.0 & 16.0 & 8.1 & 0.1 & 0.6 & 0.9 & 0.8 & 0.3 & 0.31 & 0.5 \\
\hline $\begin{array}{l}\text { 123478- } \\
\text { HxCDD }\end{array}$ & 19,000 & 21,000 & 280 & 50.0 & 680 & 610 & 240 & 84 & 1.6 & 4.9 & 12.0 & 6.6 & 6.0 & 1.5 & 3.7 \\
\hline $\begin{array}{l}\text { 123678- } \\
\text { HxCDD }\end{array}$ & 44,000 & 29,000 & 160 & 63.0 & 890 & 270 & 200 & 130 & 3.8 & 2.2 & 6.1 & 2.6 & 2.6 & 0.9 & 1.6 \\
\hline $\begin{array}{l}\text { 123789- } \\
\text { HxCDD }\end{array}$ & 20,000 & 12,000 & 77.0 & 32.0 & 390 & 140 & 110 & 58.0 & 2.1 & 1.9 & 2.8 & 2.5 & 2.0 & 0.8 & 1.1 \\
\hline $\begin{array}{l}\text { 1234678- } \\
\text { HpCDD }\end{array}$ & 560,000 & 660,000 & 15,000 & 1700 & 13,000 & 3900 & 6100 & 1600 & 40.0 & 72.0 & 160 & 100 & 79.0 & 43 & 33.0 \\
\hline OCDD & $2,400,000$ & $7,100,000$ & $1,000,000$ & 61,000 & 98,000 & 34,000 & 140,000 & 13,000 & 370 & 1500 & 2700 & 1700 & 1600 & 1200 & 690 \\
\hline $\begin{array}{l}\text { Total } \\
\text { PCDDs }\end{array}$ & $3,045,000$ & $7,823,300$ & $1,015,600$ & 62,900 & 113,000 & 39,000 & 146,700 & 14,900 & 400 & 1600 & 2900 & 1800 & 1700 & 1200 & 730 \\
\hline $\begin{array}{l}\text { 2378- } \\
\text { TeCDF }\end{array}$ & 0.0 & 0.0 & 81.0 & 1.5 & 4.0 & 32.0 & 8.0 & 2.2 & 1.2 & 1.3 & 1.3 & 1.9 & 1.0 & 1.4 & 1.1 \\
\hline $\begin{array}{l}\text { 12378- } \\
\text { PeCDF }\end{array}$ & 6500 & 6300 & 390 & 28.0 & 160 & 550 & 68.0 & 22.0 & 1.1 & 4.6 & 3.2 & 5.1 & 4.2 & 2.1 & 6.3 \\
\hline $\begin{array}{l}\text { 23478- } \\
\text { PeCDF }\end{array}$ & 1900 & 2000 & 41.0 & 4.7 & 35.0 & 100 & 16.0 & 5.6 & 0.2 & 1.0 & 0.9 & 0.8 & 0.9 & 0.15 & 0.6 \\
\hline $\begin{array}{l}\text { 123478- } \\
\mathrm{HxCDF}\end{array}$ & 25,000 & 39,000 & 45.0 & 140 & 730 & 1500 & 350 & 130 & 4.5 & 20.0 & 19.0 & 22.0 & 20.0 & 2.2 & 8.1 \\
\hline $\begin{array}{l}\text { 123678- } \\
\text { HxCDF }\end{array}$ & 5000 & 4800 & 5.0 & 16.0 & 98.0 & 68.0 & 31.0 & 16.0 & 0.8 & 3.6 & 3.6 & 5.9 & 3.7 & 1.7 & 1.4 \\
\hline $\begin{array}{l}\text { 123789- } \\
\text { HxCDF }\end{array}$ & 4000 & 400 & 10.0 & 1.1 & 9.0 & 2.7 & 9.0 & 1.7 & 0.1 & 0.3 & 0.2 & 0.2 & 0.4 & 0.15 & 0.1 \\
\hline $\begin{array}{l}\text { 234678- } \\
\mathrm{HxCDF}\end{array}$ & 2300 & 1700 & 4.0 & 3.4 & 37.0 & 55.0 & 22.0 & 3.1 & 0.2 & 2.0 & 1.1 & 2.3 & 2.7 & 0.38 & 1.3 \\
\hline $\begin{array}{l}\text { 1234678- } \\
\text { HpCDF }\end{array}$ & 21,000 & 65,000 & 900 & 120 & 750 & 500 & 580 & 100 & 3.8 & 23.0 & 21.0 & 28.0 & 24.0 & 4.8 & 9.6 \\
\hline $\begin{array}{l}\text { 1234789- } \\
\text { HpCDF }\end{array}$ & 8900 & 22,000 & 90.0 & 27.0 & 230 & 86.0 & 150 & 34.0 & 1.0 & 2.9 & 5.0 & 4.2 & 3.2 & 0.4 & 1.1 \\
\hline OCDF & 170,000 & 750,000 & 2700 & 720 & 6200 & 2300 & 3200 & 850 & 17.0 & 62.0 & 120 & 85.0 & 73.0 & 12 & 32.0 \\
\hline $\begin{array}{l}\text { Total } \\
\text { PCDFs }\end{array}$ & 244,600 & 891,200 & 4300 & 1100 & 8300 & 5200 & 4400 & 1200 & 30 & 121 & 175 & 155 & 133 & 25 & 61.5 \\
\hline $\begin{array}{l}\text { Total } \\
\text { PCDDs/ } \\
\text { DFs }\end{array}$ & $3,289,600$ & $8,714,500$ & $1,019,900$ & 64,000 & 121,300 & 44,200 & 151,100 & 16,100 & 430 & 1721 & 3100 & 2000 & 1800 & 1200 & 791.6 \\
\hline $\begin{array}{l}\sum \mathrm{TEQ} \\
\qquad(\mathrm{PCDD} / \mathrm{Fs})\end{array}$ & 22,000 & 22,000 & 400 & 65 & 550 & 490 & 220 & 77 & 2.5 & 6.3 & 8.6 & 7.4 & 6.2 & 2.1 & 3.6 \\
\hline
\end{tabular}

profiles at various depths were similar, and the inventory profiles are dominated by OCDD (5691\%), H7CDD (1-17\%), and OCDF (1-9\%). This corresponds well with the impurities in PCP (OCDD: 76\%; H7CDD: 10.4\%; OCDF: 10\%) used in China (Bao et al., 1995), suggesting that the contamination of PCDD/DFs in the Nanpaiwu River and Bohai Bay might stem from the use or production of PCP pesticide. Complete identification of sources will, however, require further investigation.

Co-PCBs were also detected and the concentrations are shown in Table 2. PCB77, PCB118, and PCB105 were found to be dominant and the inventory profiles are very similar with those of co-PCB in PCP pes- 
Table 2

Concentrations (pg/g dry wt) of co-PCB in the sediment from the Nanapaiwu River and Bohai Bay, North China

\begin{tabular}{|c|c|c|c|c|c|c|c|c|c|c|c|c|c|c|c|}
\hline \multirow[t]{2}{*}{ Depth $(\mathrm{cm})$} & \multicolumn{4}{|l|}{ C-1 } & \multicolumn{4}{|l|}{$\mathrm{C}-2$} & \multicolumn{7}{|l|}{ C-3 } \\
\hline & $0-5$ & $25-30$ & $85-90$ & $135-140$ & $0-5$ & $50-55$ & $95-100$ & $135-140$ & $0-5$ & $45-50$ & $65-70$ & $85-90$ & $105-110$ & $125-130$ & $145-150$ \\
\hline PCB77 & 64,000 & 37,000 & 220 & 75.0 & 1200 & 1100 & 340 & 200 & 4.4 & 15.0 & 15.0 & 530 & 13.0 & 6.5 & 7.0 \\
\hline PCB81 & 0.0 & 1900 & 22.0 & 1.9 & 50.0 & 8.2 & 0.0 & 6.8 & 0.2 & 0.0 & 0.1 & 0.2 & 0.6 & 0 & 0.1 \\
\hline PCB126 & 8300 & 8100 & 58.0 & 15.0 & 140 & 220 & 54.0 & 27.0 & 0.9 & 1.5 & 1.9 & 13.0 & 1.1 & 0.23 & 1.0 \\
\hline PCB105 & 26,000 & 52,000 & 100 & 81.0 & 510 & 590 & 130 & 160 & 4.8 & 14.0 & 17.0 & 7.1 & 14.0 & 5.2 & 10.0 \\
\hline PCB114 & 1800 & 20,000 & 7.0 & 2.4 & 20.0 & 140.0 & 9.0 & 43.0 & 0.2 & 0.8 & 0.9 & 0.3 & 0.6 & 0.18 & 0.4 \\
\hline PCB118 & 49,000 & 85,000 & 310 & 160 & 1700 & 3900 & 1000 & 310 & 12.0 & 47.0 & 47.0 & 51.0 & 50.0 & 28 & 39.0 \\
\hline PCB123 & 0.0 & 1900 & 42.0 & 10.0 & 110 & 220 & 23.0 & 27.0 & 0.7 & 2.1 & 1.9 & 0.8 & 1.9 & 0.9 & 1.3 \\
\hline PCB169 & 0.0 & 1400 & 6.0 & 0.8 & 14.0 & 22.0 & 4.0 & 2.2 & 0.1 & 0.2 & 0.4 & 0.6 & 0.3 & 0.15 & 0.2 \\
\hline PCB156 & 19,000 & 38,000 & 50.0 & 53.0 & 410 & 490 & 110 & 73.0 & 2.7 & 8.2 & 10.0 & 6.4 & 8.1 & 9.6 & 8.9 \\
\hline PCB157 & 8000 & 22,000 & 78.0 & 36.0 & 270 & 160 & 33.0 & 57.0 & 1.8 & 3.0 & 5.9 & 2.3 & 3.1 & 1.6 & 2.0 \\
\hline PCB167 & 12,000 & 26,000 & 100 & 38.0 & 300 & 390 & 54.0 & 64.0 & 2.4 & 5.1 & 8.0 & 3.5 & 5.0 & 5.2 & 3.9 \\
\hline PCB189 & 4600 & 22,000 & 87.0 & 25.0 & 220 & 110 & 29.0 & 32.0 & 1.0 & 3.4 & 5.2 & 4.0 & 3.5 & 3.7 & 3.3 \\
\hline $\begin{array}{l}\text { Total } \\
\text { Co-PCBs }\end{array}$ & 500 & 1100 & 315,300 & 192,700 & 5000 & 7400 & 1800 & 1000 & 31.1 & 100 & 113 & 620 & 101 & 61.3 & 77.1 \\
\hline $\begin{array}{l}\sum \text { TEQ } \\
\quad(\mathrm{Co}-\mathrm{PCBs})\end{array}$ & 2.0 & 6.0 & 880 & 860 & 15.0 & 23.0 & 5.7 & 2.9 & 0.1 & 0.2 & 0.2 & 1.4 & 0.1 & 0.0 & 0.1 \\
\hline
\end{tabular}

ticides made in China (Kim, 2002). Additionally, the concentration of co-PCBs varies almost linearly relative to that of PCDDs/DFs $\left(r^{2}=0.803, n=15\right)$. Finally, relationships between concentrations of $\mathrm{PCDD} / \mathrm{Fs} / \mathrm{co}-$ $\mathrm{PCB}$ and TOC in surface section from $\mathrm{C}-1, \mathrm{C}-2$, and C3 were also found (Fig. 4). A seaward decreasing trend in $\mathrm{PCDDs} / \mathrm{Fs}$, co-PCB was observed from estuary to the Bohai Bay, which was similar with those of $\mathrm{HCHs}$ and HCB. The above results suggests that the four groups of contaminants might have common sources, and $\mathrm{PCDD} / \mathrm{Fs}$ and co-PCB contamination in Bohai Bay might be mainly due to the riverine discharge.

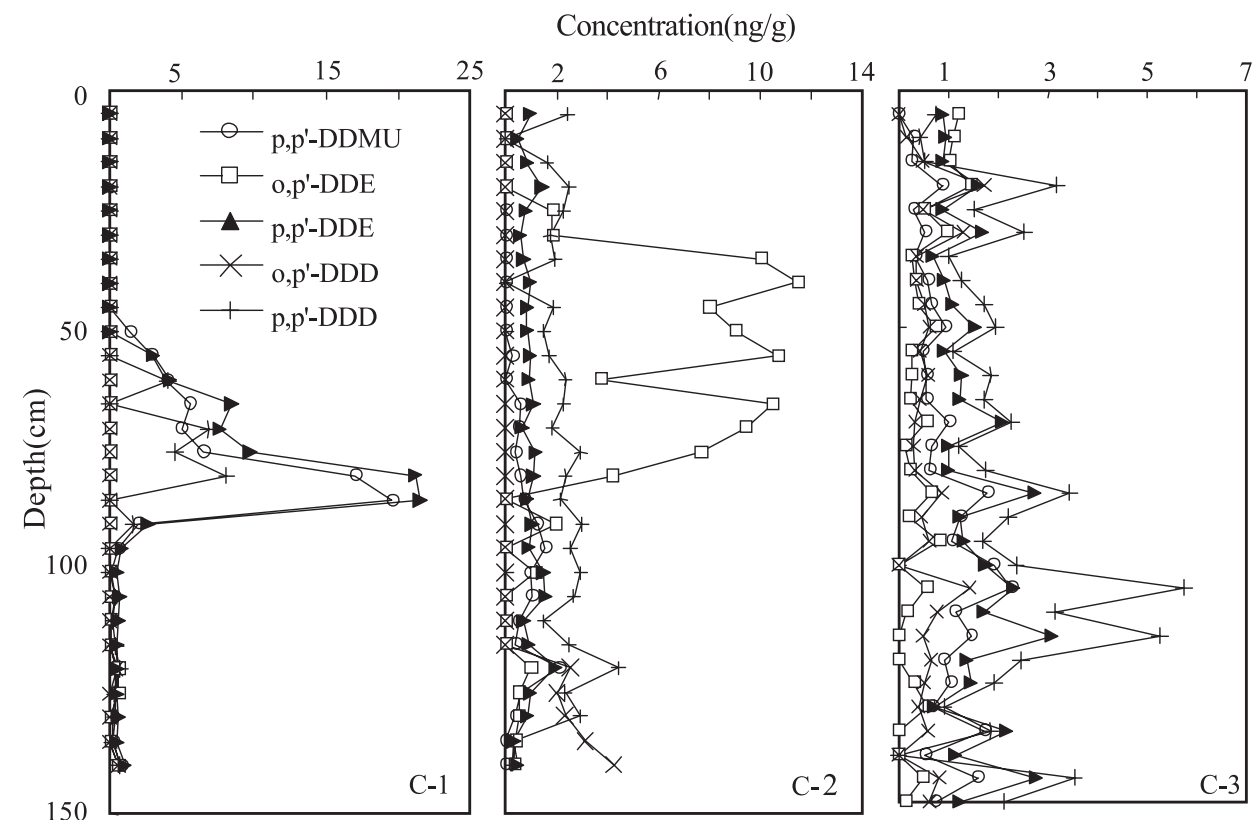

Fig. 5. Vertical profiles of DDT concentrations in sedimentary cores. C-1, C-2: sedimentary cores from the Nanpaiwu River; C-3: from Bohai Bay. 


\subsection{DDTs}

Fig. 5 shows the vertical profiles of DDTs in the three sedimentary cores from the Nanpaiwu River and Bohai Bay. The total DDT concentrations are much lower than the levels detected in the San Francisco Bay (Venkatesan et al., 1999) and the Palos Verdes Shelf, CA (Eganhouse et al., 2000). For C-1, DDTs were only detected in depths from 50 to $95 \mathrm{~cm}$ (maximum concentration: $46.2 \mathrm{ng} / \mathrm{g}$ ) suggesting that no DDTs had recently been discharged into the
Nanpaiwu River above C-1. For C-2, markedly different profiles were found: a high total concentration was observed at depths from 30 to $90 \mathrm{~cm}$, where $o, p$-DDE accounted for more than $60 \%$ of total DDTs. The sedimentary profiles of $p, p^{\prime} \mathrm{DDE}$ and $p, p^{\prime}$ DDD were relatively uniform, while $p, p$-DDMU; $o, p^{\prime}$ DDE; and $o, p$-DDD were not detected in the surface layers. In contrast, all of the five DDTs were detected in core $\mathrm{C}-3$. The total concentration of DDTs ranged from 1.6 to $12.3 \mathrm{ng} / \mathrm{g}$ dry $\mathrm{wt}$, and the sedimentary profile was relatively uniform. While $p, p^{\prime}$-DDD was
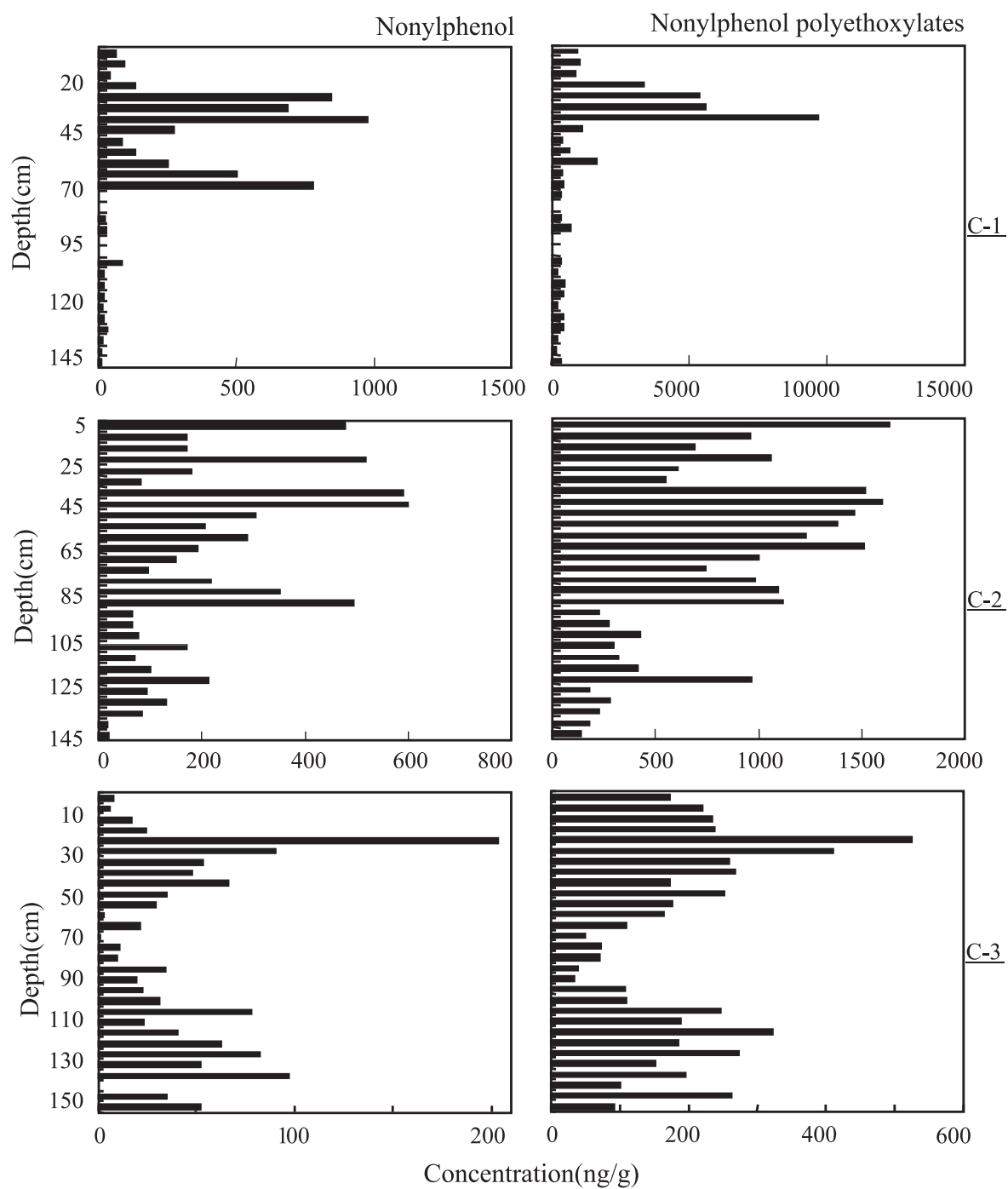

Fig. 6. Vertical profiles of nonylphenol (NP) and nonylphenol polyethoxylates (NPEOs) concentrations in sedimentary cores: C-1, C-2: sedimentary cores from the Nanpaiwu River; C-3: sedimentary core from Bohai Bay. 
the most abundant at depths below $20 \mathrm{~cm}, o, p$-DDE was the most abundant congener close to the sediment surface.

From the above distinctive congener and vertical profiles in the three cores, it can be inferred that the contribution of DDTs to Bohai Bay from the Nanpaiwu River was relatively minor. Moreover, since environmental levels of $o, p$-DDD and $o, p$-DDE are often lower than that of $p, p$-DDD and $p, p$-DDE, we attribute the relatively high levels of $o, p^{\prime} \mathrm{DDE}, o, p^{\prime}$ DDD to the production or utilization of dicofol pesticide. The composition of dicofol is about 3.54$10.78 \%$ DDT, with $o, p$-DDT as the major DDT compound, followed by $o, p$-DDE and $p, p$-DDE (Mao, 1995). Thus, only $p, p$-DDT in industrial DDT is transferred to dicofol in a dicofol-manufacturing process, and $o, p$-DDT remains in the pesticide as an impurity, and is biodegraded into $o, p$-DDE/ $o, p^{\prime}$-DDD in the environment following the use or production of dicofol pesticide.

\subsection{NP and NPEOs}

Fig. 6 shows variations of NP and NPEOs in the three cores. For all three cores, the vertical profiles of NP are quite similar to those of NPEOs, indicating that the occurrence of NP is related to NPEOs. From $\mathrm{C}-1$ and $\mathrm{C}-2$ to $\mathrm{C}-3$, the concentrations of NP and NPEOs follow a decreasing trend. However, depth variations of NP and NPEOs in each core are different. For C-1, a high concentration zone appears above $70 \mathrm{~cm}$, and maximum concentrations of NP and NPEOs (970 and $9700 \mathrm{ng} / \mathrm{g}$ dry wt, respectively) occurred at $35 \mathrm{~cm}$. The mean ratio of NPEOs to NP was estimated to be 7.7. For C-2, NP and NPEOs increased gradually with the decrease of depth, indicating increasing discharge of the pollutants in the upper stream. The highest concentration (NP: 589 ng/g dry wt, NPEO: $1600 \mathrm{ng} / \mathrm{g}$ dry wt) was about 10 times higher than the lowest concentration (NP: 17.8 ng/g dry wt, NPEO: 143 ng/g dry wt). The concentration profiles of NP and NPEOs in C-3 showed a bimodal distribution. This profile of NP is largely different from that in Tokyo Bay which shows subsurface maximum of NP concentration (Isobe et al., 2001). The highest concentrations of NP and NPEOs were 203 and $524 \mathrm{ng} / \mathrm{g}$ dry wt, respectively. While the concentration of NP in the Nanpaiwu River was similar with that in Sumidagawa River in Japan, the concentration of NP in Bohai Bay was much lower than the concentration in the core from Tokyo Bay. There is no correlation between NP or NPEOs and TOC in sediment. Because the total concentrations of NP and NPEOs in the cores from the Nanpaiwu River were about 15 times higher than those in the core from Bohai Bay, the Nanpaiwu River was potentially a source of NP and NPEOs to Bohai Bay sediments. The mean ratio of NPEOs to NP was 4.9 for site C-2 which is lower than that in $\mathrm{C}-1$. From this result, there is a need to investigate whether the biodegradation from NPEOs into NP occurred during the riverine discharge.

\section{Conclusions}

The occurrence of trace organic contaminants (HCHs, HCB, penta-CB, PCDD/Fs, co-PCBs, DDTs, NP, and NPEOs) in sediments from Bohai Bay and its adjacent Nanpaiwu River, North China was examined. Comparison of the vertical profiles among these compounds is effective to discuss the possible sources of the target contaminants. While $\mathrm{HCHs}$, $\mathrm{HCB}, \mathrm{PCDD} / \mathrm{Fs}$, and co-PCB in Bohai Bay appear to share a common source, i.e., the riverine discharge from Nanpaiwu River, the pollution of DDTs in Bohai Bay was from different sources. Input from the Nanpaiwu River is responsible for the majority of NP and NPEOs in Bohai Bay. Determination of the pollution history of these organic contaminants in this region will require further geochemical characterization and development of sediment chronologies.

\section{Acknowledgments}

Financial supports of National Basic Research Program of China [2003CB415004], Japan International Cooperation Agency, and the National Natural Science Foundation of China [49925103 and 40024101] are gratefully acknowledged. The manuscript benefited greatly from the comments of $\mathrm{H}$. Takada (Tokyo University of Agriculture and Technology, Fuchu, Tokyo, Japan) and an anonymous reviewer. 


\section{References}

Bao, Z.H.C.H., Wang, K., Kang, J.X., Zhao, L.W., 1995. Analysis of polychlorinated dibenzo- $p$-dioxins and polychlorinated dibenzofurans in pentachlorophenol and sodium pentachlorophenate. Environ. Chem. 14 (4), 317-321.

Bard, S.M., 1999. Global transport of anthropogenic contaminants and the consequences for the Arctic marine ecosystem. Mar. Pollut. Bull. 38, 356-379.

Connell, D.W., Fung, C.N., Minh, T.B., Tanabe, S., Lam, P.K.S., Wong, B.S.F., Lam, M.H.W., Wong, L.C., Wu, R.S.S., Richardson, B.J., 2003. Risk to breeding success of fish-eating Ardeids due to persistent organic contaminants in Hong Kong: evidence from organochlorine compounds in eggs. Water Res. 37, 459-467.

Czuczwa, J.M., Hites, R.A., 1984. Environmental fate of combustion-generated polychlorinated dioxins and furans. Environ. Sci. Technol. 18, 444-450.

Eganhouse, R.P., Pontolillo, J., Leiker, T.J., 2000. Diagenetic fate of organic contaminants on the Palos Verdes Shelf, California. Mar. Chem. 70, 289-315.

Glynn, P.W., Rumbold, D.G., Snedaker, S.C., 1995. Organochlorine pesticide-residues in marine sediment and biota from the northern Florida reef tract. Mar. Pollut. Bull. 30, $397-402$.

Isobe, T., Nishiyama, H., Nakashima, A., Takada, H., 2001. Distribution and behavior of nonylphenol, octylphenol, and nonylphenol monoethoxylate in Tokyo metropolitan area: their association with aquatic particles and sedimentary distributions. Environ. Sci. Technol. 35, 1041-1049.

Iwata, H., Tanabe, S., Sakai, N., Nishimura, A., Tatsukawa, R., 1994. Geographical distribution of persistent organochlorines in air, water and sediments from Asia and Oceana, and their implications for global redistribution from lower latitudes. Environ. Pollut. 85, 15-33.

Jobling, S., Sumpter, P., 1993. Detergent components in sewage effluent are weakly oestrogenic to fish: an in vitro study using rainbow trout (Oncorhynchus mykiss) hepatocytes. Aquat. Toxicol. 27, 361-372.

Jonkers, N., Laane, R.W.P.M., De Voogt, P., 2003. Fate of nonylphenol ethoxylates and their metabolites in two Dutch estuaries: evidence of biodegradation in the field. Environ. Sci. Technol. 37, 321-327.

Juttner, I., Henkelmann, B., Schramm, K.W., Steinberg, C.E.W., Winkler, R., Kettrup, A., 1997. Occurrence of PCDD/F in dated lake sediments of the Black Forest, southwestern Germany. Environ. Sci. Technol. 31, 806-812.

Khim, J.S., Kannan, K., Villeneuve, D.L., Koh, C.H., Giesy, J.P., 1999. Characterization and distribution of trace organic contaminants in sediment from Masan Bay, Korea: 1. Instrumental analysis. Environ. Sci. Technol. 33, 4199-4205.

Kim, H.K., 2002. Origin of dioxins in drinking water and the effect of water treatment for the minimization of dioxins, Graduate School of Engineering Hokkaido University, Japan, Doctoral thesis.
Kjeller, L.O., Rappe, C., 1995. Time trends in levels, patterns, and profiles for polychlorinated dibenzo- $p$-dioxins, dibenzofurans, and biphenyls in a sediment core from Baltic proper. Environ. Sci. Technol. 29, 346-355.

Liu, C.H., Wang, Z.H.Y., He, G., Wu, Y.S.H., 2003. Investigation of water quality in the estuaries around Bohai Bay. Environ. Pollut. Control 25 (4), 222-225.

Lye, C.M., Frid, C.L.J., Gill, M.E., Cooper, D.W., Jones, D.M., 1999. Estrogenic alkylphenols in fish tissues, sediments, and waters from the U.K Tyne and Tees estuaries. Environ. Sci. Technol. 33, 1009-1014.

Mao, C.Z., 1995. Stop use and countermeasure of dicofol. China Tea 17 (4), 8-9.

Maruyama, K., Yuan, M., Otsuki, A., 2000. Seasonal changes in ethylene oxide chain length of poly(oxyethylene)alkylphenyl ether nonionic surfactants in three main rivers in Tokyo. Environ. Sci. Technol. 34, 343-348.

Miyamoto, J., Klein, W., 1998. Environmental exposure, species differences and risk assessment. Pure Appl. Chem. $70,1829-1845$.

Nalor, C.G., 1996. Proceedings of the CESIO 4th World Surfactants Congress, Barcelona, Spain. European Committee on Surfactants and Detergents, Brussels, Belgium, pp. 378-391.

Shang, D.Y., Macdonald, R., Ikonomou, M.G., 1999. Persistence of nonylphenol ethoxylate surfactants and their primary degradation products in sediments from near a municipal outfall in the strait of Georgia, British Columbia, Canada. Environ. Sci. Technol. 33, 1366-1372.

Shao, B., Hu, J.Y., Yang, M., 2002. Determination of nonylphenol ethoxylates in the aquatic environment by normal phase liquid chromatography-electrospray mass spectrometry. J. Chromatogr., A 950, 167-174.

Simonich, S.L., Hites, R.A., 1995. Global distribution of persistent organochlorine compounds. Science 269, 1851-1854.

Soto, A.M., Justicia, H., Wray, J.W., Sonnenschein, C., 1991. $p$-Nonyl-phenol: an estrogenic xenobiotic released from "modified" polystyrene. Environ. Health Perspect. 92, $167-173$.

Tanabe, S., Iwata, H., Tatsukawa, R., 1994. Global contamination by persistent organochlorines and their ecotoxicological impact on marine mammals. Sci. Total Environ. 154, 163-177.

Thiele, B., Gunther, K., Schwuger, M.J., 1997. Alkylphenol ethoxylates: trace analysis and environmental behavior. Chem. Rev. 97, 3247-3272.

Vartiainen, T., Mannio, J., Korhonen, M., Kinnunen, K., Strandman, T., 1997. Levels of PCDD, PCDF and PCB in dated lake sediments in subarctic Finland. Chemosphere 34, 1341-1350.

Venkatesan, M.I., de Leon, R.P., Van Geen, A., Luoma, S.N., 1999. Chlorinated hydrocarbon pesticides and polychlorinated biphenyls in sediment cores from San Francisco Bay. Mar. Chem. 64, $85-97$.

Weber, K., Goerke, H., 1996. Organochlorine compounds in fish off the Antarctic Peninsula. Chemosphere 33, 377-392.

White, R., Jobling, S., Hoare, S.A., Sumpter, J.P., Parker, M.G., 1994. Environmentally persistent alkylphenolic compounds are estrogenic. Endocrinology 135, 175-182. 
Willett, K.L., Ulrich, E.M., Hites, R.A., 1998. Differential toxicity and environmental fates of hexachlorocyclohexane isomers. Environ. Sci. Technol. 32, 2197-2207.

Wu, W.Z., Schramm, K.W., Henkelmann, B., Xu, Y., Yediler, A., Kettrup, A., 1997. PCDD/F-s, PCBs, HCHs and $\mathrm{HCB}$ in sediments and soils of $\mathrm{Ya}-\mathrm{Er}$ lake area in China: results on residual levels and correlation to the organic carbon and particle size. Chemosphere 34, $191-202$.
Yamashita, N., Kannan, K., Imagawa, T., Villeneuve, D.L., Hashimoto, S., Miyazaki, A., Giesy, J.P., 2000. Vertical profile of polychlorinated dibenzo- $p$-dioxins, dibenzofurans, naphthalenes, biphenyls, polycyclic aromatic hydrocarbons, and alkylphenols in a sediment core from Tokyo Bay, Japan. Environ. Sci. Technol. 34, 3560-3567. 